\title{
The Effect of Financial Leverage and Market Size on Stock Returns on the Ghana Stock Exchange: Evidence from Selected Stocks in the Manufacturing Sector
}

\author{
Prince Acheampong ${ }^{1}$, Evans Agalega ${ }^{1} \&$ Albert Kwabena Shibu ${ }^{2}$ \\ ${ }^{1}$ Department of Accountancy, Koforidua Polytechnic, P.O.Box KF981, Koforidua, Ghana \\ ${ }^{2}$ Ghana Commercial Bank Ltd., Ghana \\ Correspondence: Prince Acheampong, Department of Accountancy, Koforidua Polytechnic, P.O.Box KF981, \\ Koforidua, Ghana. E-mail: owoahene6@yahoo.com
}

Received: December 5, 2013

Accepted: December 27, 2013

Online Published: January 10, 2014

doi:10.5430/ijfr.v5n1p125

URL: http://dx.doi.org/10.5430/ijfr.v5n1p125

\begin{abstract}
In this paper we investigate the effect of financial leverage and market size of selected stocks on stock returns. Ordinary Least Square (OLS) regression methods were used to model the relationship between the dependent variable and the independent variables. The leverage of the selected firms were estimated from the annual financial reports covering a period of five years (i.e.2006-2010) of selected five corporations operating in the manufacturing sector. Furthermore, average monthly stock prices of the selected stocks between 2006-2010 for Unilever, Pioneer Kitchenware, PZ Cussions, Aluworks and Camelot making up the five selected companies were used. The study established a negative and significant relationship between leverage and stock return when the overall industrial data is used. However at the individual firm level the relationship was not stable. Four out of the five selected companies (i.e. PZ, Unilever, Aluworks and Camelot) all had associated leverage coefficients to be negative. Pioneer Kitchenware however, had positive leverage coefficient. The study also found the relationship between Size and stock returns to be positive and significant. The size effect within the manufacturing sector was however very limited.
\end{abstract}

Keywords: leverage, returns, financial risk, risk-free, investor

\section{Introduction}

Investors invest for anticipated future returns, but those returns can rarely be predicted precisely as there will almost always be risk associated with investments. Actual or realized returns will almost always deviate from expected returns anticipated in the beginning of the investment period. It is assumed that investors will prefer investments with the highest expected return suitable to their risk aversion (Bodie et al. 2008)). Financial risk for a firm is commonly associated with the form of financing. The greater the amount of debt a firm uses to finance its operation, the higher the financial risk. The risk stems from the firm not being able to meet its financial obligations. This has given rise to a thought in finance of the unambiguous relationship between capital structure and return on equity.

The seminal work of Modigliani-Miller (1958) introduced the proposition that the expected return on equity should increase with the amount of debt in a firm's capital structure in a friction market. Theoretical finance regards leverage as one of the sources of risk, and thus claims that the more levered a firm is, the higher the risk for equity holders. As the risk-averse equity holders are exposed to more uncertain cash flows, they will demand a higher rate of return on their investment (equity) (Penman et al, 2007). Chai and Zhang, (2010) noted when a firm has high leverage, a further increase in its leverage ratio can materially increase the likelihood of default and its expected cost. If the default risk is priced, a significant increase in the leverage should lead to a higher expected future return. Smith (2002) described leverage as the use of borrowed money to make an investment and return on that investment. It is more risky for a company to have a high ratio of financial leverage. It has also been noticed that on the outcome of financial leverage: if the level or point of financial leverage is high, the more rise is anticipated profit on company's equity. Thus, financial leverage is used in various circumstances as a means of altering the cash flow and financial position of a company. 
In view of the aforementioned, capital structure decisions are critical as a shift in leverage could increase or decrease the financial strains on companies. Lintner (1956) and Gordon (1959) argued that there exists an optimal leverage ratio that equates the marginal benefits of debt such as tax shields to the marginal costs of debt such as increase in expected bankruptcy costs. Modigliani-Miller (1958), on the other hand, argued rigorously that the value of a firm is independent of its capital structure. The immediate implication of this proposition was that the return on equity capital is an increasing function of leverage. This is because debt increases the riskiness of the stock and hence equity shareholders will demand a higher return on their stocks.

Muradoglu and Sivaprasad (2008) suggest that since capital structure is endogenous, it is possible that the optimal financial policy is one that advocates low leverage, so as to mitigate agency problems while preserving financial flexibility. The negative relationship between returns and leverage could also be due to the market's pricing of the firm's ability to raise funds if need be Myers (1977). Myers argues that higher leverage increases the probability of a firm forgoing positive NPV projects in the future, because in some instances, the pay-off from these investments to shareholder after fulfilling debt obligations is lower than the initial investment shareholders have to outlay. This under-investment reduces the growth option value of a firm. Thus, an increase in the leverage ratio can result in a lower stock price, all other factors equal. Researchers including Chai and Zhang, (2010) noted that firms with high leverage increase their likelihood of default and its expected cost. According to them, if the default risk is priced, a significant increase in the leverage should lead to a higher expected future return.

Despite its centrality within finance, empirical findings on this subject have been mixed and sometimes contradictory (Penman et al, 2007). While some authors (Hamada, 1972; Bhandari, 1988; Dhaliwal et al, 2006) show that returns increase with leverage; other authors show that returns decrease with leverage (Korteweg, 2009; Dimitrov and Jain, 2008, Penman et al, 2007; Muradoglu and Sivaprasad, 2009). The resolution of this issue for the practical conduct of operations in the world's capital market seems important. Accordingly this paper explores the link between leverage and stock returns, contributing towards the existing empirical evidence of asset pricing implications of leverage. Furthermore, the empirical data that have been used to test this proposition have predominantly derived from firms in the United States; there is therefore the need to test the robustness of this proposition in a different environment and more importantly in a developing country. This has served as a motivation for the current paper.

\section{Literature Review}

We discus below the key concepts associated with the subject matter of this paper.

\subsection{The Concept of Stock}

In simple terms a stock refers to a share in the ownership of a company. Stock represents a claim on the company's assets and earnings. The percentage stake that an investor holds is reflected in the number of stocks the investor acquires from the company's stocks. Thus the more shares that one acquires, the greater his/her ownership rights in the company.

When one holds a company's stock, it means that person is one of the many owners (shareholders) of the company and as such has a claim (albeit usually very small) to everything the company owns. An investor's share ownership is represented by a stock certificate. That is a piece of paper which serves as a proof to one's ownership. According to Brigham and Ehrhardt (2009), an ordinary stock simply represents an ownership interest in a corporation. In this modern age of business however, such certificates are rarely given the shareholder because the brokerage firms keep these records electronically otherwise known as holding shares "in street name". This is done in an attempt to make the stock easily tradable. Unlike in the past where one has to physically take a share certificate to the brokerage in order to sell, now with just a click on the mouse or even a phone call; stocks can be easily traded.

\subsection{Return}

Return refers to the financial rewards gained as a result of making an investment. The nature of the return depends on the form of the investment. For instance a company that invests in fixed assets and business operations expects returns in the form of profit, which may be measured on before -interest, before tax or after tax basis, and in the form of increased cash flows. An investor who buys ordinary shares expects returns in the form of dividend payment and capital gains (share price increases). Again, an investor who buys corporate bonds expects regular returns in the form of interest payments (Frimpong, 2010).

\subsection{Risk}

When an individual investor or a company makes an investment, they anticipate or expect a particular return. However the actual return that these investors receive may be greater or lesser than what they expected. Risk has been defined as 
the possibility that the actual return may be different from the expected return. When the actual return receive is greater than what was expected, investors are happy. On the other hand, investors, companies, and financial managers are more likely to be worried with the possibility that the actual return is less than the expected return. Therefore, a risky investment is one where there is a significant possibility of its actual returns being lower or higher than its expected return (Frimpong, 2010).

\subsection{Risk and Return Relationship}

Investors invest for anticipated future returns, but those returns can rarely be predicted precisely as there will almost always be risk associated with investments. Actual or realized returns will almost always deviate from expected returns anticipated in the beginning of the investment period. It is assumed that investors will prefer investments with the highest expected return suitable to their risk aversion (Bodie et al. (2008)).

Risk in a financial context can be interpreted as the level of uncertainty. Risk per se is a broad concept, and the risk pertaining to an investor is very different to the risks a firm is exposed to. The risk-return tradeoff in financial markets implies that low levels of risk are associated with low returns and that high levels of risk imply high returns. Assuming investors are risk averse, they will require a compensation for bearing risk. This risk compensation takes the form of a risk premium, which is defined as the expected return less the risk-free rate (Bodie et al. 2008)).

Financial risk for a firm is commonly associated with the form of financing. The greater the amount of debt a firm uses to finance its operation, the higher the financial risk. This risk stems from the firm not being able to meet its financial obligations.

\subsection{Measures of Leverage}

According to Rajan and Zingales (1995), the objective of a study has an essential influence on the measure of leverage. Thus, one should first think of what the objective of the study is. Total liabilities to total assets is the broadest definition of leverage, but this, as Rajan and Zingales (1995) argue, is not a good proxy for financial risk, since many balance sheet items included in total liabilities are used for transaction purposes rather than financing.

The next step after providing a definition of leverage is to decide on an appropriate measure. The previous papers written on this subject have a mixed attitude to the use of book value or market value. The use of either book or market value of leverage can yield different conclusions, for example as presented by Gomes and Schmid (2008). Titman and Wessels (1988) argued that the coefficients in the factor model may vary depending on whether book or market values are used. As we will use market values of equity for estimating returns, one might argue that market values of debt would be better for any comparison. Although the use of market values of debt can have its advantages over book value, we have to consider what measures of debt are available. As book values are more readily available as opposed to market values, we are inclined to use the book values of debt this paper.

\subsection{Debt to Equity Ratio (DER)}

According to Ross, Westerfield and Randolph (2002), DER is a proxy for estimating the level of leverage of a company. A company with high DER may provide higher returns to its shareholders, in line with the risk that is faced by the company compared to other companies with lower DER.

Debt to Equity $=\underline{\text { Total Debt }}$

Total Equity

According to Werner and Jones (2004), DER shows a proportional relationship between debt and equity. A lower DER means that total debt is relatively lower compared to total equity. The DER of a company are evaluated from a few perspectives, namely (1) the DER of comparable companies, (2) At which business stage the company is in (new companies tend to have more debt), (3) Company's policy that considers the optimum level of debt financing. According to Bhandari (1988), a natural proxy for the risk of common equity of a firm is that firm's (DER). An increase in the DER of a firm increases the risk of its common equity, measuring risk in any reasonable way.

\section{Empirical Methodology}

The empirical procedures adopted for this paper are as discussed below.

\subsection{Sources and Type of Data}

This study used Secondary data. The data for the selected stocks were obtained from the Ghana Stock Exchange database. The leverage of the selected firms were estimated from the annual financial reports covering a period of five years (i.e.2006-2010) of selected five corporations operating in the manufacturing sector. Furthermore, average monthly stock prices of the selected stocks between 2006-2010 for Unilever, Pioneer Kitchenware, PZ Cussions, 
Aluworks and Camelot making up the five selected companies were used. The respective market capitalizations of selected companies which are proxies for size were likewise sourced from the Ghana stock exchange.

\subsection{Empirical Model Specification}

$$
R_{i t}=\alpha+\beta_{1} L E V E R A G E+\beta_{2} S I Z E+\varepsilon_{i t}
$$

Where,

$R_{i t}$ is the return for stock $\mathrm{i}$ in period $\mathrm{t}$,

$\alpha$ is the constant of the regression equation representing other factors that could have had an effect on the stock return,

$\beta_{1}$, and $\beta_{2}$ are the co-efficient of the estimates and

$\varepsilon_{\text {it }}$ is the error term.

\subsubsection{Estimations of Model Parameters}

\subsubsection{Stock Return (Dependent Variable)}

The estimation of the stock returns for the selected stocks was as in the equation (2) below:

$$
r_{t}=\left(\frac{p_{t-} p_{t-1}}{p_{t-1}}\right) \times 100 \%
$$

Where,

$r_{t}$ is stock return for period $t$,

$\mathrm{P}_{\mathrm{t}}$ is the market price of stock $\mathrm{i}$ in period $\mathrm{t}$,

$\mathrm{P}_{\mathrm{t}-1}$ is the market price of stock $\mathrm{i}$ in period $\mathrm{t}-1$

The stock price data for the analyses were gathered from the GSE data base. Daily closing stock prices of the selected stocks were averaged to get the monthly stock prices used for the analyses. Stock market data covering the period of (2006-2010) were used for the analyses.

\subsubsection{Leverage (Independent Variable)}

The leverage of the various selected stocks was estimated using the equation (3) below:

\section{Leverage $(\%)=\underline{\text { Long term debt }+ \text { Short term debt \& Current Portion of Long term debt }}$}

Total Capital + Short term debt \& Current Portion of Long term debt

The data for the leverage estimations were extracted from the yearly published financial statements of the selected stocks. Financial statements also covering the period from 2006-2010 were used.

\subsubsection{Size (Independent Variable)}

The Size of each selected stock as used in this research refers to the market capitalization of the stock.

This is estimated by multiplying the number of common stocks issued by the firm by the closing stock market price of the stock.

\section{Presentation of Results, Analysis and Discussion}

\subsection{Descriptive Statistics}

Table 1. Descriptive statistics for manufacturing sector

\begin{tabular}{lccc}
\hline & Stock Returns & Leverage & Size \\
\hline Std. deviation & 0.24626 & 0.17874 & 0.46086 \\
\hline Mean & 0.931231 & 0.34469 & 0.246265 \\
\hline Observation & 5 & 5 & 5 \\
\hline
\end{tabular}

Source: Author's own construct, 2012.

As highlighted in Table 1, Size has the largest standard deviation of approximately 0.46086 . This implies that selected companies differ to some extent in terms of their market capitalization. The mean leverage ratio in the manufacturing sector as shown in Table 1 is 0.344 which signifies lower debt levels in the sector. The associated standard deviation of leverage (0.1789) is the lowest among the three variables. This signifies greater similarities in the level of debt as far as the selected companies are concern. 


\subsection{Effect of Size and Leverage on Stock Returns}

Table 2. Results of OLS for manufacturing sector as a whole

\begin{tabular}{lll}
\multicolumn{3}{c}{ Dependent Variable: Stock returns } \\
\cline { 2 - 4 } Coefficient & -0.394 & Size \\
\hline Standard Error & 0.139 & 0.009 \\
\hline T-Statistics & $-2.835^{* *}$ & $9.228^{* *}$ \\
\hline $\mathbf{R}^{2}$ & 0.756 & \\
\hline $\mathbf{D W}$ & 0.879 & \\
\hline
\end{tabular}

$* *=5 \%$ significance level

The study employed ordinary least squares to estimate coefficients of the regression model. The robustness of parameter coefficients are used to explain the relationship between stock returns and the selected independent variables. The results of the estimations by ordinary least squares are presented in Table 2 above. The general model constructed for the manufacturing sector as a whole (with respect to the selected stocks) had an associated Durbin Watson (DW) statistic of less than 2 as shown in Table 2 above. This clearly gives an indication that the data series used for the estimations are free from autocorrelation. Moreover, the Co-efficient of determination $\left(\mathrm{R}^{2}\right)$ for the model is 0.756. The coefficient of determination gives an indication of how the independent variables in the regression model explain the total variation in the dependent variable. For a time series data, an $\mathrm{R}^{2}$ of 0.5 and above is said to be good and acceptable for analysis. The $\mathrm{R}^{2}$ value obtained for this study (0.756) indicates that the independent variables; leverage and Size explained $75.6 \%$ of the total variations in stock returns. The remaining $24.4 \%$ of variation is explained by other factors not included in this model. The Leverage coefficient is negative and statistically significant for the manufacturing sector. For every $1 \%$ fall in leverage, stock returns will increase by $0.394 \%$ in the manufacturing sector which comprises Unilever, Camelot, PZ, Pioneer Kitchenware and Aluworks. The associated t-statistics is greater than two (i.e. 2.835). This may be due to the fact that firms that belong to the manufacturing sector may try to maintain low leverage levels due to the risk involved with high levels of leverage. Another possible explanation for this result may be due to the fact that financial institutions in Ghana are unwilling to lend to manufacturing sector due to their perceived uncompetitiveness and hence their debt requirements would be relatively lower than other major sectors.

\subsection{Relationship between Stock Returns and Leverage (Firm level)}

Table 3. Relationship between stock returns and leverage

\begin{tabular}{llll}
\hline STOCK & Coefficient & $\begin{array}{l}\text { Standard } \\
\text { Error }\end{array}$ & T-Statistics \\
\cline { 2 - 4 } Unilever & -24.051 & 14.163 & -1.698 \\
\hline PZ Cussons & -0.566 & 0.278 & $-2.510^{* *}$ \\
\hline Aluworks & -0.038 & 0.201 & -0.189 \\
\hline Camelot & -0.012 & 0.023 & 0.530 \\
\hline Pioneer Kitchen & 0.00001 & 0.062 & 0.340 \\
\hline
\end{tabular}

$* *=$ Significance at $5 \%$ level

Table 3 shows the OLS results for the individual firms in the manufacturing sector selected for this paper. In the case of Unilever it can be inferred from Table 3 that leverage has an estimated co-efficient of $\mathbf{- 2 4 . 0 5}$ and a standard error of 14.16. Thus, there is an inverse relationship between the stock returns and leverage for Unilever stocks. This result implies that a $1 \%$ decrease in financial leverage causes as much as $24.05 \%$ increase in stock returns. Conversely a $1 \%$ increase in debt/financial leverage will cause a $24.05 \%$ decrease in stock returns. Interestingly, the estimated t-statistics is $\mathbf{1 . 6 9 8}$ which is less than 2. Thus, the results obtained for Unilever with respect to the relationship between leverage and stock returns is statistically insignificant and therefore, the results could not be used for any meaningful forecasting or could not be relied upon for future estimations. With respect to PZ Cussons, it could be observed that the estimated coefficient of leverage for PZ is - $\mathbf{0 . 5 6 6}$. That is to say that there is an inverse relation between leverage and stock returns for PZ. The implication of this result is that a $1 \%$ decrease in leverage causes a 
$0.566 \%$ increase in stock returns. The estimated t-statistic is 2.510 which is greater than 2 , signifying that the coefficient is statistically significant. Furthermore, Aluworks has a leverage coefficient of $\mathbf{- 0 . 0 3 8}$ with a standard error of 0.201. This result also implies an inverse relationship between leverage and stock returns with respect to Aluworks' stock. Thus a $1 \%$ increase in leverage will cause stock returns to decrease by $0.038 \%$. However, as can be seen from the Table 3 above, the t-statistics is 0.189 which is less than 2 and indicates that the result is statistically insignificant.

Similarly, result shown in Table 3 above indicates that Camelot leverage has a negative relationship with stock returns. Specifically, the leverage coefficient was estimated to be about $\mathbf{- 0 . 0 1 2}$ and an associated t-statistics of $\mathbf{- 0 . 5 3 0}$ which is less than 2 and also implying that the result is statistically insignificant for future forecasting and meaningful predictions.

Finally, Pioneer Kitchenware as seen in Table 3 has an estimated positive leverage coefficient of 0.00001 indicating a direct relationship between leverage and stock returns. The result specifically means that a $1 \%$ increase in financial leverage of pioneer kitchenware will increase its stock returns by $0.00001 \%$. Moreover the t-statistics for this leverage estimation is 0.340 . Thus, the t-statistic value falls way below the minimum value of 2 implying that the result is statistically insignificant.

In summary, the results show that the relation between leverage and stock returns can go in opposite directions with respect to the individual companies. For example Pioneer kitchen recorded a positive relationship between leverage and stock returns but Unilever, PZ, Camelot and Aluworks all had estimations that showed a negative relationship between leverage and stock returns. As a result, the relation between total leverage and stock returns seems unstable, a result that is consistent with the literature. However, this conditional relation is largely masked when one uses a total leverage measure in the whole manufacturing sector. The estimated leverage coefficient for the whole sector indicates a negative and statistically significant relationship with stock returns.

It may be argued that the unstable nature of the relationship between leverage and stock returns seems to depend on debt maturity. Specifically there is a positive relationship between stock return and relatively shorter-term debt, but negative for relatively long-term debt issuance. This also implies that comparable to all other companies in the study Pioneer Kitchenware has relatively shorter debt.

Miller and Modigliani (hereafter MM) made a proposition in a seminal paper that returns to equity increase with leverage. MM finds that the returns increase with leverage in the utilities and oil and gas sectors. But this empirical test carried out within the manufacturing sector indicates otherwise. The findings show leverage to have a negative relation with stock returns in the overall sample. The research has found that returns have a negative relation with leverage in the manufacturing sector. The evidence presented here has clear implications that leverage has an important role to play in explaining stock returns. However, the relationship is not uniform even for stocks in the same industry.

The implication is that empirical findings of MM in the other sectors, namely utilities and oil \& gas sectors cannot be generalized into all sectors, bearing in mind that these two sector employed by MM are highly regulated and leverage ratios are concentrated. Firms may be able to increase their leverage with implications to the cost of capital.

Furthermore, the desirability of debt financing for a firm partly depends on its operating leverage. The operating leverage of a firm refers to the extent to which fixed cost is built into the firms operations. Manufacturing companies in general have high fixed cost associated with machinery and highly specialised staff who are paid even in period where the firms are not operating. The higher the operating leverage of a firm, the less desirable is debt financing (financial leverage). Thus, leverage increases the riskiness of firms' stock which should theoretically be commensurate with higher returns. However in an inefficient market, information flow is very weak and the market participants are unable to benefit from such happenings.

Another possible reason could be economic, where the availability of cheap debt has enabled firms to take advantage of cheap credit for expansion and profitable investments. This may have led to firms in the portfolios to experience high stock returns even after deductibility of the cost of capital. Last but not least, another possible explanation may be due to the fact that the asymmetry of information between firms and outside investors could affect firms' financing choices and capital structure decisions.

\subsection{Relationship between Stock Returns and Capitalization (Size)}

The evidence that small firms (originally characterized as firms with small market equity values) earns higher returns on average than large firms have attracted much attention from both academics and practitioners. Banz (1981) was 
the first to document this phenomenon, referred to in the literature as the size effect. In this study, market capitalization is used as a proxy for Size.

Table 4. Relationship between stock returns and capitalization (Size)

\begin{tabular}{llll}
\hline STOCK & Coefficient & $\begin{array}{l}\text { Standard } \\
\text { Error }\end{array}$ & T-Statistics \\
\hline Unilever & 0.021 & 0.003 & $7.869^{* *}$ \\
\hline PZ Cussons & 19.342 & 0.02 & $2.5281^{* *}$ \\
\hline Aluworks & 0.041 & 0.010 & $4.243^{* *}$ \\
\hline Camelot & 0.060 & 0.026 & $2.285^{* *}$ \\
\hline Pioneer Kitchen & -0.009 & 0.02 & $-5.177^{* *}$ \\
\hline
\end{tabular}

The results of the effect of size on stock returns for the selected stocks are as presented in Table 4 above. In the case of Unilever the result as presented in Table 4 above shows that size has positive relationship with stock returns. The results as indicated above shows that a $1 \%$ decrease in market capitalization will cause stock returns to decrease about $0.021 \%$. Conversely, the result also reveals that, a $1 \%$ increase in market capitalization will also increase stock returns by $0.021 \%$ for Unilever stocks. The t-statistic for the estimated coefficient is $\mathbf{7 . 8 6 9}$ which is more than 2 implying that the result is statistically significant.

The size effect on stock returns for PZ Cussons is positive. The results as shown in Table 4 above indicate that there is a direct relationship between firm size and stock returns for PZ. It could be seen that a $1 \%$ increase in market capitalization (size) causes $19.342 \%$ increase in stock returns. Statistically, the t-statistic for PZ is $\mathbf{2 . 2 8 1}$ and it is greater than 2 implying that the result is statistically significant. The standard error for PZ with respect to size is $\mathbf{0 . 0 2}$ which indicates that the mean estimates are very reliable.

Also depicted in Table 4 above is the result of the OLS expressing the relationship between market capitalisation (size) and stock returns for Aluworks' stock. The results indicate that there exist a direct, positive relationship between stock returns and size for Aluworks. It can be seen from the Table 4 that a 1\% increase in Size causes an increase of about $0.041 \%$ in stock returns. The t-statistic of the estimated coefficient is $\mathbf{4 . 2 4 3}$ which is greater than 2 and implies that the result is statistically significant.

The result for Pioneer Kitchenware is, however, different from all the other companies under review. The study established a negative or an inverse relationship between size and stock returns in the case of Pioneer Kitchenware. Specifically, the estimated coefficient for Size is $\mathbf{- 0 . 0 0 9}$ with a t-statistics of -5.170 as shown in Table 4 above. It could be observed from the Table 4 above that a $1 \%$ increase in the independent variable size will cause a $2.285 \%$ decrease in the dependent variable stock returns for Pioneer Kitchenware stocks. Statistically, the t-statistic for the estimated coefficient is $\mathbf{- 5 . 1 7 7}$ which in absolute terms, is greater than 2. Thus the result for Pioneer Kitchenware expressing the relationship between stock returns and market capitalization is significant. Moreover, it can be seen that Camelot size has a positive relationship with stock returns. Specifically, 1\% increase in market capitalization result in a $0.060 \%$ increase in stock returns. The associated t-statistic is 2.285 implying a statistically significant estimate.

The overall result for the manufacturing industry as seen in Table 2 indicate a positive relationship between Size and stock returns. OLS estimation shows that $1 \%$ increase in market capitalization (Size) cause an increase of approximately $0.001 \%$ in stock returns. The coefficient for Size is statistically significant since its associated t-statistics is $\mathbf{9 . 2 2 8}$. The low Size effect in the manufacturing sector could be due to the very low liquidity of shares on the Ghana stock exchange. Cheung and Lilian (1990) provide some evidence in support of the importance of liquidity in the size effect. The Authors found that the size of tradable shares is directly related to stock liquidity, the size effect of tradable shares is substantially stronger than that of non-tradable shares. This indicates that a significant component of the size effect, when size is measured by tradable shares comes from the difference in liquidity between large and small stocks. This analysis indicates that, for a given level of leverage, large companies generate lower stock returns than small ones, and that this effect increases with higher degrees of leverage. Also, larger companies have decreasing stock-price sensitivity to leverage, particularly where size is measured by total assets. In view of this fact, it appears that the limited Size effect on stock returns in the manufacturing sector is due its overall relatively large market capitalization and also highly levered companies making the Size effect on stock price very small. 


\subsection{Trend Analysis of Leverage in the Manufacturing Sector}

We also walk through the trends in financial leverage for the manufacturing sector in general. The result is presented in the Figure 1 below.

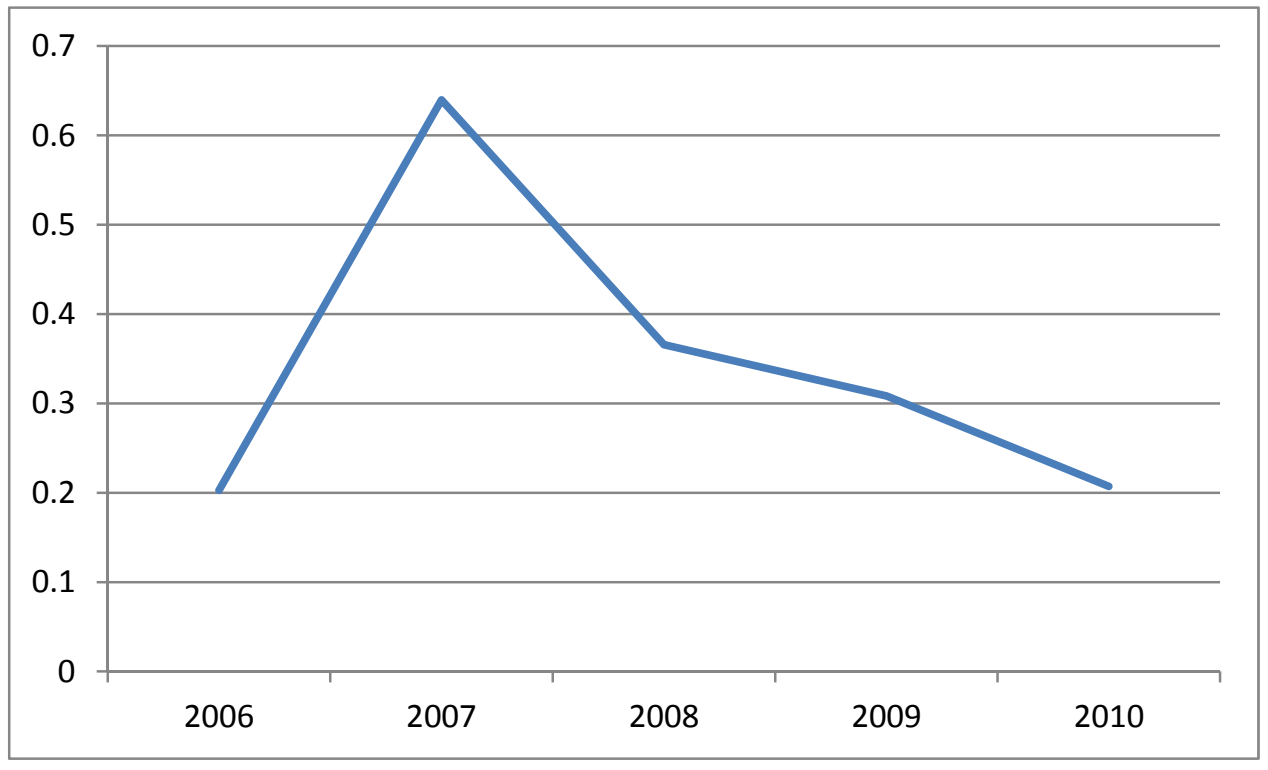

Figure 1. Trend of leverage in the manufacturing sector

Source: Author's own construct, (November, 2013)

The manufacturing sector level use of debt as can be seen from Figure 1 has been on the decline. In 2006 the ratio of debt to total capital was approximately 0.2 implying that for every one (1) cedi of total capital, $\mathbf{0 . 2}$ pesewas came from debt. But in 2007 there was an exponential rise in debt usage. The estimated leverage ratio for the sector was approximately $\mathbf{0 . 6 5}$ indicating that for every 1 cedi of total capital, 0.65 pesewas was finance by debt. This may be due to the large amount of money moving in the global financial system prior to the financial crisis. This made debt financing easier and cheaper relative to other forms of financing. As can be seen from Figure 1 above, the level of debt relative to total capital declined sharply from $\mathbf{0 . 6 5}$ pesewas per cedi to about $\mathbf{0 . 3 6}$ pesewas in 2008 . The reason for this sharp drop could be due to the significant credit crunch that came as a consequent of the global financial crisis. The decline in debt usage among companies in the manufacturing sector continued in 2009. As highlighted in Figure 1 the estimated leverage ratio was about $\mathbf{0 . 3 1}$. That is, every 1 cedi of total capital is finance by a debt of $\mathbf{0 . 3 1}$ pesewas. Another possible reason for the limited usage of debt could be due to the seemly high interest rate charges on loans in Ghana. Further it could also be due to very high profit earnings and subsequent retain earnings which results in the companies in the sector able to finance both investment and operations internally than through debt financing. Moreover the debt market (bond market) in Ghana is not yet developed and this makes it unattractive for issuing other forms of debt securities.

\subsection{Correlation among Variables}

Also the level of correlation between the variables under review was of interest to the researcher. The results from the correlation analysis are presented in Table 5 below. 
Table 5. Correlation coefficient

\begin{tabular}{llccc}
\hline & & LEVERAGE & SIZE & $\begin{array}{c}\text { STOCK } \\
\text { RETURNS }\end{array}$ \\
\hline LEVERAGE & $\begin{array}{l}\text { Pearson Correlation } \\
\text { Sig. (2-tailed) }\end{array}$ & 1 & -.059 & -.341 \\
& $\mathrm{~N}$ & 5 & & \\
& Pearson Correlation & -.059 & 1 & \\
\hline SIZE & & & & $.948^{*}$
\end{tabular}

Sig. (2-tailed) $\quad .925$

\begin{tabular}{llccc} 
& $\mathrm{N}$ & 5 & 5 & \\
\hline STOCK & Pearson Correlation & -.341 & $.948^{*}$ & 1 \\
RETURNS & Sig. (2-tailed) & .575 & .014 & \\
& $\mathrm{~N}$ & 5 & 5 & 5 \\
\hline
\end{tabular}

\section{*. Correlation is significant at the $\mathbf{0 . 0 5}$ level (2-tailed).}

The correlation coefficient is a measure of the strength of the linear trend relative to the variability of the data around that trend. Thus, it is dependent both on the magnitude of the trend and the magnitude of the variability in the data. Correlation determines the strength and the direction of a linear relationship between two variables. As reflected in Table 5, the correlation coefficient between leverage and firm size is $\mathbf{- 0 . 0 5 9}$ indicating a negative relationship between leverage and firm size but the coefficient is very weak and statistically insignificant. In the case of leverage and stock returns, results as depicted in Table 5 shows the correlation coefficient to be $\mathbf{- 0 . 3 4 1}$ a measure which is relatively stronger than correlation between leverage and size. These results are consistent with that found using the techniques of ordinary least squares approach. But similar to leverage and size the coefficient is statistically insignificant. A very strong correlation coefficient was recorded between stock returns and firm size. The correlation coefficient is both positive and significant. The result shows a correlation of $\mathbf{0 . 9 4 8}$ and significant $\mathbf{5 \%}$ level.

\section{Conclusion}

This paper has examined the relationship between expected stock returns, size, and leverage of selected firms in the manufacturing sector listed on the Ghana Stock Exchange. PZ Cussons, Unilever, Pioneer Kitchenware, Aluworks and Camelot are the five selected manufacturing companies listed on the Ghana stock that were the focus of this study. The study employed the techniques of ordinary least square regression model to estimate the coefficients of the variables. Depending on the robust nature of their coefficient the appropriate relationship and significance was determined. Furthermore, Pearson correlation among the variables was adopted to further test the validity of the results of OLS and also to establish differences or otherwise of using these two methods of coefficient estimation.

The study reveals for both independent variables (i.e. leverage and firm size) that there exists a significant relation between the respective variables and stock returns. The study established a negative and significant relation between leverage and stock return when the overall industrial data is used. However at the individual firm level the relationship was not stable. Four out of the five selected companies (i.e. PZ, Unilever, Aluworks and Camelot) all had associated leverage coefficients to be negative. Pioneer Kitchenware however, had positive leverage coefficient. The study also found the relation between Size and stock returns to be positive and significant. The size effect within the manufacturing sector was however very limited.

\section{References}

Bhandari, L. C. (1988). Debt/Equity Ratio and Expected Common Stock Returns: Empirical Evidence. Journal of Finance, 43(2), 507-528. http://dx.doi.org/10.1111/j.1540-6261.1988.tb03952.x

Bodie, Z., Kane, A., \& Marcus, A. (2008). Investments (Seventh international ed.). McGraw-Hill.

Brigham and Ehrhardt. (2009). Financial Management. Theory, and Practice, USA. 
Dhaliwal, D. S., Heitzman S., \& Zhen Li, O. (2006). Taxes, leverage, and the cost of equity capital. Journal of Accounting Research, 44(4), 691-723. http://dx.doi.org/10.1111/j.1475-679X.2006.00214.x

Dimitrov, V., \& Jain, P. C. (2008). The Value Relevance of Changes in Financial Leverage beyond Growth in Assets and GAAP Earnings. Journal of Accounting, Auditing and Finance.

Frimpong, M. J. (2010). Corporate Financial Strategy. Kumasi, KNUST Printing Press.

Gibbons, Ross, \& Shanken. (1989). ("GRS") test statistic Assuming that the $\varepsilon$ are normally distributed and independent and identically distributed the GRS formula is (Sangiorgi (2009)).

Gomes, J.F., \& Schmidt, L. (2010). Levered returns. Journal of Finance, 65, 467-494. http://dx.doi.org/10.1111/j.1540-6261.2009.01541.x

Gordon, M. J. (1959). Dividends, Earnings and Stock Prices. Review of Economics and Statistics, 41(2), 99-105. http://dx.doi.org/10.2307/1927792

Hamada, R. (1972). The Effects of the Firm's Capital Structure on the Systematic Risk of Common Stocks. Journal of Finance, (27).

Hou, K., \& Robinson, D. T. (2006). Industry Concentration and Average Stock Returns. Journal of Finance, 61(4), 1927-1956.

Korteweg, A. (2009). The Net Benefits to Leverage. Journal of Finance.

Lintner, J. (1956). Distribution of Incomes of Corporations among Dividends, Retained Earnings and Taxes. The American Economic Review, 46(2).

Modigliani, F., \& Miller, M. H. (1958). The cost of capital, corporation finance and the theory of investment. American Economic Review, 48(3).

Muradoglu, G., \& Sivaprasad, S. (2008). An Empirical Analysis of Capital Structure and Abnormal Returns. Retrieved from http://ssrn.com/abstract=948393

Myers, S. (1977). Determinants of Corporate Borrowing. Journal of Financial Economics.

Penman, S. H., Richardson, S. A., \& Tuna, I. (2007). The Book-to-Price Effect in Stock Returns: Accounting for Leverage. Journal of Accounting Research, 45(2).

Rajan, R., \& Zingales, L. (1995). What Do We Know about Capital Structure? Some Evidence from International Data. Journal of Finance, 50(5), 1421-1460.

Titman, S., \& Wessels, R. (1988). The Determinants of Capital Structure Choice. Journal of Finance, 43(1). http://dx.doi.org/10.1111/j.1540-6261.1988.tb02585.x 